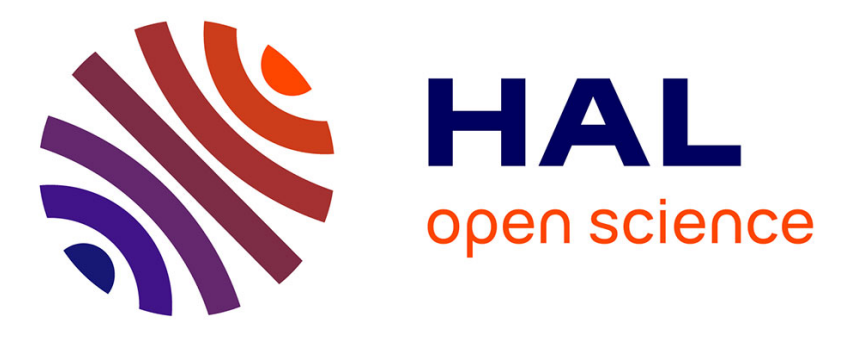

\title{
An improved methodology for integrated crop management systems
}

\author{
Jacques Lançon, Jacques Wéry, Bruno Rapidel, Moussa Angokaye, Edward \\ Gérardeaux, Christian Gaborel, Dramane Ballo, Blaise Fadegnon
}

\section{To cite this version:}

Jacques Lançon, Jacques Wéry, Bruno Rapidel, Moussa Angokaye, Edward Gérardeaux, et al.. An improved methodology for integrated crop management systems. Agronomy for Sustainable Development, 2007, 27 (2), pp.101-110. 10.1051/agro:2006037 . hal-02668513

\section{HAL Id: hal-02668513 \\ https://hal.inrae.fr/hal-02668513}

Submitted on 31 May 2020

HAL is a multi-disciplinary open access archive for the deposit and dissemination of scientific research documents, whether they are published or not. The documents may come from teaching and research institutions in France or abroad, or from public or private research centers.
L'archive ouverte pluridisciplinaire HAL, est destinée au dépôt et à la diffusion de documents scientifiques de niveau recherche, publiés ou non, émanant des établissements d'enseignement et de recherche français ou étrangers, des laboratoires publics ou privés. 


\title{
An improved methodology for integrated crop management systems
}

\author{
Jacques LANÇON ${ }^{\mathrm{a} *}$, Jacques WERY ${ }^{\mathrm{b}}$, Bruno RAPIDEL ${ }^{\mathrm{b}, \text { e }}$, Moussa ANGOKAYE ${ }^{\mathrm{c}}$, Edward GÉRARDEAUX $^{\mathrm{b}, \mathrm{d}}$, \\ Christian GABOREL ${ }^{\text {a, c }}$, Dramane BALLO $^{\mathrm{e}}$, Blaise FADEGNON $^{\mathrm{d}}$ \\ ${ }^{a}$ Centre Coopération Internationale en Recherche Agronomique pour le Développement, avenue Agropolis, BP 5035, 34032 Montpellier Cedex, France \\ ${ }^{\mathrm{b}}$ Unité Mixte de Recherche SYSTEM (Agro.M-CIRAD-INRA), bât. 27, 2 place Viala, 34060 Montpellier Cedex, France \\ ${ }^{\mathrm{c}}$ Institut de Recherche Agronomique pour le Développement, Centre Nord, BP 22, Maroua, Cameroun \\ ${ }^{\mathrm{d}}$ Institut National de Recherches Agricoles du Bénin, CRA Coton et Fibres, 01 BP 715, Cotonou, Bénin \\ ${ }^{\mathrm{e}}$ Institut d'Économie, Rurale, BP 258, Bamako, Mali
}

(Accepted 18 December 2006)

\begin{abstract}
Designing innovative combinations of techniques to improve the sustainability of a cropping system is a major challenge in many regions of the world. The available techniques are often added together, and assessed for yield only, rather than combined in an integrated approach. We than developed here a methodology to design and assess a sustainable crop management system adapted to a specific set of constraints. Based on the prototyping approach, this methodology takes advantage of expert knowledge on cotton cropping techniques such as no-till, cover crop, varieties and growth regulator, with innovative potential but which are not yet properly simulated by actual crop models. It involves four successive steps: (1) identification of the local sets of constraints to crop production, and selection of relevant criteria for sustainability assessment, (2) elaboration of a cropping system prototype and its assessment indicators adapted to a target set of constraints, (3) on-station assessment and adjustment of the prototype, and (4) on-farm evaluation and adjustment of the prototype. We describe here the methodology, and how its first three steps were implemented to build and test a prototype for late-planted cotton with low input availability in West Africa. A new cropping system was designed, which included new genotypes, increased plant stand, lower rates of fertilisers and the use of herbicides and growth regulators. Fourteen indicators were selected to assess the economic, environmental and social performance of the prototype. The prototype was then tested in Mali, Cameroon, and Benin in 2002 and 2003. Our findings show that this prototype improved farmers' income by about $+35 \%$ in 2002 and $+20 \%$ in 2003, and increased labour productivity by about +5 to $+20 \%$. It achieved a satisfactory environmental performance, similar to the control, with positive mineral balances. The prototype still requires extra labour, skill and money to implement, and therefore requires further adjustment.
\end{abstract}

sustainable cotton management system / west Africa / prototyping / multi-criteria evaluation

\section{INTRODUCTION}

Cotton-growing has long been promoted throughout West African savannahs with relatively uniform cropping recommendations (CMDT, 2001). The sector underwent significant changes during the past 15 years: after 1993's devaluation of the local currency, the cotton area almost tripled and the number of cotton growers doubled. Privatisation of the sector was completed in Benin, while it is still under way in other countries. The ecological and socio-economic conditions under which the crop is grown have changed: new areas, some of them less fertile, new farmers, new organisations. At the same time, cotton yields have declined in most West African countries and, recently, cotton prices fell abruptly on the international market.

The uniform crop management system recommended to farmers no longer copes with the diversity of growers and conditions. Farmers are asking for a wider range of cropping techniques, better adapted to the actual constraints, and cotton research has to develop innovative cropping strategies. Abun-

* Corresponding author: jacques.lancon@cirad.fr dant literature refers to the development of new cropping systems. They can be classified into four methodological groups:

- Factorial experiments are usually performed on-station. Extensively conducted in West Africa (e.g. Cretenet and Vaissayre, 1986), they combine a limited number of techniques, options or levels of such techniques. They are suited to analysing the interactions between 2-3 factors, but they hardly produce innovative and operational cropping systems.

- Analysis of farmers' practices (Haefele et al., 2001) and agronomic appraisal (Rapidel et al., 2006) may produce locally adapted systems (David et al., 2005), but their potential for innovation is usually limited because they rely only on the existing techniques.

- Computer models can simulate a very high number of cropping systems and explore a wide diversity of soils and climates (Dogliotti et al., 2004; Loyce et al., 2002). But they have two shortcomings. They require extensive preliminary experiments to adjust the model parameters to the local environment. And often, they cannot simulate the impact of new techniques on biological processes, as could be the case with no tillage or integrated pest management. 
The prototyping methodology (Vereijken, 1997) is a comprehensive approach to building integrated cropping systems adapted to farmers' constraints and objectives. It combines regional diagnosis to identify the constraints and objectives, expert knowledge to build innovative cropping systems and on-farm experimentation to assess and adjust the system. This method can quickly produce innovative cropping systems, and disseminate them among pilot farms. In return, the size of the on-farm experimental network limits the number of systems under test, and the exploration of their domain of validity.

We found the prototyping approach appropriate for improving the sustainability of the cotton-cropping systems used in West Africa. Previous research had produced numerous experimental results and wide expert knowledge on innovative techniques, e.g. stand density effects (Hau and Goebel, 1987), growth regulator (Joly, 1976) and protection strategies (Cauquil and Vaissayre, 1994), which could hardly be included in the existing simulation models such as GOSSYM (Baker et al., 1983) or Ozcot (Hearn, 1994), even after calibration. We adapted this approach in order to produce innovative Cotton Management Systems, which could integrate the full range of techniques available on the crop (including new varieties), and could be adapted to the diversity of constraints and goals of sustainable agriculture. This article describes how the methodology was set up and tested on-station across three African countries: Benin, Cameroon and Mali.

\section{MATERIALS AND METHODS}

\subsection{A four-step methodology}

To elaborate a new crop management system, scientists had to consider simultaneously techniques, cropping constraints, growers' objectives and their interactions. The effect of each factor (variety, stand, growth regulator, etc.) having been previously established independently (e.g. CIRAD, 1999), the scientists were asked to combine them to fit a particular or target set of constraints. The proposed methodology involved four major steps (Fig. 1), of which three (Step 1, Step 2 and part of Step 3) were implemented in Benin, Cameroon and Mali.

\subsection{Organisation of experts' work}

This research was conducted through intensive interactions among scientists and cotton management system users (farmers, extension agents and ginners). Four workshops were held in Montpellier (France, July 2001, Maroua (Cameroon, October 2001), Sotuba (Mali, October 2001) and Cotonou (Benin, March 2003), each one bringing general or local relevant information to implement the different steps of the approach (Tab. I).

The scientific workshop held in France required general and multidisciplinary scientific knowledge and know-how on the crop and on the available set of techniques. Among the 43 participants, 32 scientists were specialised in the field of agronomy, physiology, crop management, crop protection or plant

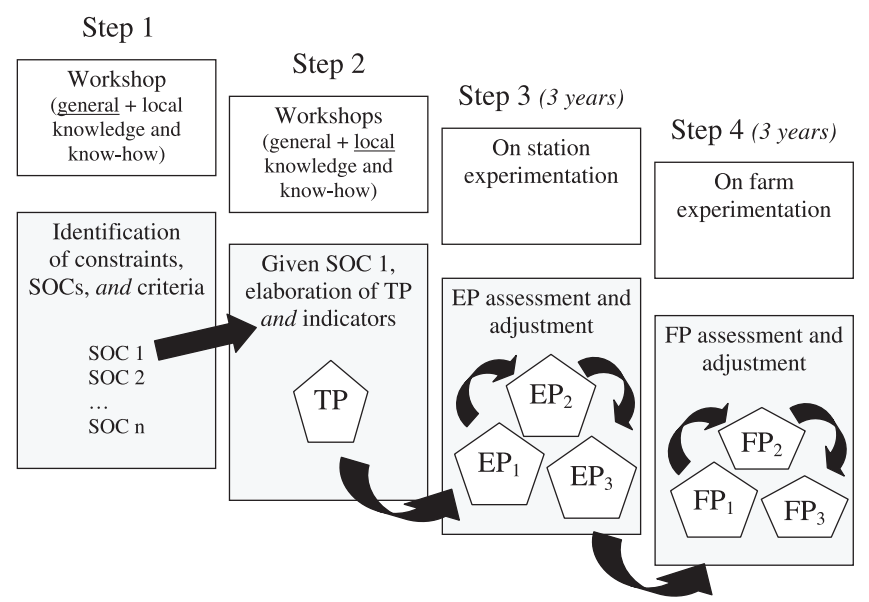

Figure 1. The four steps of the crop management system prototyping method. Step 1: identification of the major sets of constraints (SOCs) to cotton production across the region, and selection of criteria to assess the prototypes. Step 2: elaboration of a theoretical prototype adapted to a target set of constraints, and elaboration of criteriaderived indicators to assess the prototype. Step 3: on-station assessment and adjustment of the experimental prototype (EP1 to EP3). Step 4: on-farm evaluation and adjustment of the farmers' prototype (FP1 to FP3).

breeding, and 9 in micro- or macro-economy. All had previous ground experience in cotton-growing in West Africa. The local workshops (Maroua, Sotuba and Cotonou) were managed by the scientists, and were intended to promote interactions between science and local knowledge, among scientists and local stakeholders. Several field visits and discussions with extension specialists or farmers favoured the sharing of information on local needs, users' demand and constraints.

\subsection{Step 1. Identification of constraints, sets of constraints and criteria}

During the scientific workshop, the participants had to group the biophysical and socio-economic constraints to cotton production into homogeneous sets of constraints and to propose relevant criteria to assess the performance of a cotton management system. Three groups of local experts presented their review of the major constraints encountered by the cotton farmers in Benin, Cameroon and Mali, including agronomic, social, economic and environmental aspects of cottongrowing. Each review combined expertise and the results of local farm or field surveys (e.g. Dugué and Floquet, 2000). In a second session, we divided the participants into 4 balanced groups with similar geographic experience. From the constraints quoted in the reviews, the participants had a limited time (45 min) to propose six major sets of constraints, either widespread, or country-specific but with a high improvement potential. Out of a total of 24 sets of constraints proposed by the groups, six were retained during the synthesis. Each group also had to propose a list of criteria to assess the prototype 
Table I. Description of the full methodology to design cotton management systems: three steps have already been achieved, the fourth is on its way. Three categories of collective work were mobilized, either at regional or local scale. The regional scientific workshop (RWS) which initiated the process was held in Montpellier, France, in June 2001: it mainly gathered experienced scientists in cotton production. Three local workshops (LW) followed, involving local scientists, farmers and experts in cotton production, in Maroua (Cameroon, October 2001), Sotuba (Mali, October 2001) and Cotonou (Benin, March 2003). Finally, the agronomists in charge of the field experimentation had also to coordinate through regional meetings and workshops (RWA, eg Cotonou, March 2003)).

\begin{tabular}{|c|c|c|}
\hline Step & Expected output & Method \\
\hline \multirow[t]{5}{*}{$\begin{array}{l}\text { 1. Identification of constraints, sets of } \\
\text { constraints (SOCs) and criteria }\end{array}$} & $\begin{array}{l}\text { To review existing diagnosis (farm } \\
\text { surveys) }\end{array}$ & $\begin{array}{l}\text { Farms and plots surveys, gathering of expert knowledge } \\
\text { in each country }\end{array}$ \\
\hline & To define and select common SOCs & $\begin{array}{l}\text { RWS: Regional workshop with scientists covering the ma- } \\
\text { jor aspects of cotton production }{ }^{\dagger} \text { in Africa or Latin } \\
\text { America, } 1 \text { extensionist and } 1 \text { farmer }\end{array}$ \\
\hline & $\begin{array}{l}\text { To check the local relevance of the } \\
\text { selected SOCs }\end{array}$ & $\begin{array}{l}\text { LW: Local workshops, formal and informal meetings with } \\
\text { scientists and stakeholders, especially farmers and other } \\
\text { experts in cotton production }\end{array}$ \\
\hline & To choose a target SOC & RWS: Synthesis of the national surveys. \\
\hline & $\begin{array}{l}\text { To check the local relevance of the } \\
\text { target SOC }\end{array}$ & LW \\
\hline \multirow[t]{4}{*}{$\begin{array}{l}\text { 2. Elaboration of the theoretical prototype } \\
\text { (TP) and the assessment indicators }\end{array}$} & $\begin{array}{l}\text { To adapt the disciplinary points of } \\
\text { view to the target SOC }\end{array}$ & $\begin{array}{l}\text { RWS: The scientists explain the crop growth pattern con- } \\
\text { sidered as optimum by their discipline }\end{array}$ \\
\hline & $\begin{array}{l}\text { To integrate the disciplinary views } \\
\text { and to design the theoretical proto- } \\
\text { type (TP) }\end{array}$ & $\begin{array}{l}\text { RWS: The scientists work in multidisciplinary groups to } \\
\text { reach a consensus about (i) the ideal crop growth pattern } \\
\text { and (ii) the way to achieve it (TP) }\end{array}$ \\
\hline & To choose the assessment criteria & $\begin{array}{l}\text { RWS: The scientists work in multidisciplinary groups to } \\
\text { propose a list of criteria and indicators }\end{array}$ \\
\hline & $\begin{array}{l}\text { To check the local relevance of the } \\
\text { proposed assessment criteria }\end{array}$ & LW \\
\hline \multirow[t]{3}{*}{$\begin{array}{l}\text { 3. On station evaluation of the experimental } \\
\text { prototype (EP) }\end{array}$} & $\begin{array}{l}\text { To adapt the TP to the local context } \\
\text { (EP) }\end{array}$ & $\begin{array}{l}\text { LW: Scientists and local experts propose minor local } \\
\text { adaptations of the TP, which becomes EP }\end{array}$ \\
\hline & $\begin{array}{l}\text { To assess and adjust the EP after on } \\
\text { station experimentation }\end{array}$ & $\begin{array}{l}\text { RWA: Regional workshop with the agronomists in charge } \\
\text { of the field experimentation }\end{array}$ \\
\hline & To assess and adjust the EP & $\begin{array}{l}\text { LW: from the results of } 1 \text { to } 3 \text { years of multisite on station } \\
\text { experimentation in the three countries }\end{array}$ \\
\hline \multirow[t]{3}{*}{$\begin{array}{l}\text { 4. On farm evaluation of the farmer } \\
\text { prototype (FP) }\end{array}$} & $\begin{array}{l}\text { To adapt the EP to the local context } \\
\text { (Farmer Prototype, FP) }\end{array}$ & $\begin{array}{l}\text { LW: Scientists and local experts including framers, pro- } \\
\text { pose local adaptations of the EP, which becomes FP }\end{array}$ \\
\hline & $\begin{array}{l}\text { To assess and adjust the FP after on } \\
\text { farm experimentation }\end{array}$ & RWA \\
\hline & To assess and adjust the FP & $\begin{array}{l}\text { LW: from the results of } 1 \text { to } 3 \text { years of multisite on farm } \\
\text { experimentation in each country }\end{array}$ \\
\hline
\end{tabular}

$\dagger$ With special skill in breeding, plant protection, growing, national and international marketing, or fibre processing.

contribution to sustainable agriculture, and its potential adoption by farmers and other stakeholders.

\subsection{Step 2. Elaboration of the theoretical prototype and the assessment indicators}

During the regional scientific workshop, the participants had to target one specific set of constraints and to design a theoretical prototype adapted to these constraints, by combining disciplinary ideal growth patterns. The target set of constraints could either concern a large number of cotton growers, or offer a real opportunity for developing an alternative cotton management system.

By mobilising their disciplinary point of view (genetics, entomology, technology, agronomy, economy or sociology), several scientists described how an efficient cotton crop should develop in this particular environment. Again, we divided the participants into groups with balanced disciplinary skills. Each group had to adapt and combine the disciplinary points of view to the situation summarised in the target set of constraints. The participants agreed on the best way to fulfil the yield expectation and to control the biophysical constraints associated with the target set of constraints. The consensus they 
Table II. Major sets of constraints for cotton production in West Africa. They were derived from local surveys and diagnosis studies which were presented during the initial scientific workshop (Montpellier, 2001). A consensus among cotton experts from four countries and different scientific disciplines was then attained on these sets of constraints.

\begin{tabular}{|c|c|c|c|c|}
\hline \multicolumn{2}{|c|}{ Set of constraints } & \multicolumn{2}{|l|}{ Major constraints } & Geographic zones \\
\hline 1 & Inadequate rainfall & $\begin{array}{l}\begin{array}{l}\text { On the biophysical } \\
\text { sub-system }\end{array} \\
\text { Short agricultural season } \\
\text { Water stress }\end{array}$ & $\begin{array}{l}\begin{array}{l}\text { On the technical } \\
\text { sub-system }\end{array} \\
\text { No specific constraint }\end{array}$ & $\begin{array}{l}\text { Dry areas (500 mm in } 4 \text { months) } \\
\text { Late-planted plots }\end{array}$ \\
\hline 2 & $\begin{array}{l}\text { Low soil fertility } \\
\text { due to land limitation }\end{array}$ & Weed pressure & $\begin{array}{l}\text { No fallow, } \\
\text { rapid rotation }\end{array}$ & $\begin{array}{l}\text { Densely populated areas } \\
\text { Areas with rapidly growing population } \\
\text { (no land tenure) } \\
\text { Everywhere, specific plots }\end{array}$ \\
\hline 3 & High rainfall and humidity & $\begin{array}{l}\text { Specific pests/ } \\
\text { high pressure } \\
\text { Double pick rainfall }\end{array}$ & $\begin{array}{l}\text { Lack of animal } \\
\text { draught power } \\
\text { draught power }\end{array}$ & Humid and pre-forestry areas \\
\hline 4 & Risky economic contexts & No specific constraint & $\begin{array}{l}\text { Poorly organised sector } \\
\text { Farmers looking for limited } \\
\text { levels of cash investments }\end{array}$ & $\begin{array}{l}\text { Specific countries } \\
\text { Specific farms }\end{array}$ \\
\hline 5 & $\begin{array}{l}\text { Land available, } \\
\text { manpower rare } \\
\text { or expensive }\end{array}$ & No specific constraint & $\begin{array}{l}\text { No easy access to } \\
\text { capital investment } \\
\text { Land is hoarded as capital } \\
\text { No or little cattle-raising }\end{array}$ & $\begin{array}{l}\text { Newly open land } \\
\text { Sparsely populated areas }\end{array}$ \\
\hline 6 & $\begin{array}{l}\text { Mechanised systems } \\
\text { (profit }+ \text { sustainability) }\end{array}$ & No specific constraint & $\begin{array}{l}\text { Manpower rare or expensive } \\
\text { High level of capital } \\
\text { investment }\end{array}$ & $\begin{array}{l}\text { Capitalistic farming } \\
\text { Mechanised biggest African farms }\end{array}$ \\
\hline
\end{tabular}

reached provided a framework for crop performance elaboration. It was translated by the groups of participants into a new combination of techniques, adapted from the currently used cotton management system and called the theoretical prototype. Time was limited $(90 \mathrm{~min})$ to force the consensus. The prototypes produced by all groups were then discussed and unified during the plenary session. Finally, the participants had to elaborate indicators to assess the prototype on the basis of criteria identified in Step 1. In order to collect useful field data to test the actual effect of each modified technique, the experts also proposed a list of indicators to monitor the crop and analyse its performance at various levels (individual plants, organs, products, cover and biomass) These indicators of the biophysical system functions were used in Step 3 for adjustment of the prototype (not described in this paper).

\subsection{Step 3. On-station evaluation of the experimental prototype}

During the local workshops, the theoretical prototype was adapted to the local context for the purpose of experimentation (Fig. 1). It became the experimental prototype while being tested on-station for its technical feasibility and its performance, relative to the recommended cotton management system.

\subsubsection{Experimental design}

The experimental prototype was compared with the control cotton management system in 14 tests, in Kodek, Guiring, Makebi, Sanguere (Cameroon) and Farako and Sotuba (Mali) in 2002 and in Gobe, Ketou, Okpara, Angaradébou (Benin), Kodek (Cameroon), Ntarla, Farako and Sotuba (Mali) in 2003. The control was as recommended for cotton-growing by the extension services of the cotton development companies. The prototype and control were compared in a complete Fisher block design with three to four replications. Each elementary plot was $8 \mathrm{~m}$ wide and $20 \mathrm{~m}$ long $\left(160 \mathrm{~m}^{2}\right)$. In order to fit with the target environmental conditions of the chosen set of constraints (\#1 in Tab. II), the trials were sown during the first three weeks of July.

\subsubsection{Growing conditions}

Soils were of the typical Ferruginous type, with a predominance of sands (5 situations) or sandy-loams (9 situations). Most soils were slightly acid, with a $\mathrm{pH}$ around 6, varying from 5.2 in Makébi (Cameroon) to 7.3 in Gobé (Benin). Their content of organic matter (20 upper $\mathrm{cm}$ ) varied from $0.41 \%$ in Farako (Mali) to $2.31 \%$ in Okpara (Benin). On average, the major nutrients were present in reasonable concentrations for $\mathrm{N}(0.37 \mathrm{~g} / \mathrm{kg}), \mathrm{P}(10 \mathrm{mg} / \mathrm{kg})$ and $\mathrm{K}(0.20 \mathrm{meq} / 100 \mathrm{~g})$, 
with higher concentrations in Okpara and Gobé (Benin) and lower ones in Kodek and Sanguéré (Cameroon) or Farako (Mali). The variations corresponded to the observed range in the cotton-growing area of West Africa. The climate was drier in 2002 than in 2003. From 10 days before sowing until the end of the flowering period, the average rainfall amounted to $483 \mathrm{~mm}$ in 2002 and $667 \mathrm{~mm}$ in 2003. Variations between sites were significant in both years, the minimum being reached at Makébi and Sanguéré (Cameroon) with less than $380 \mathrm{~mm}$ at 2002 and the maximumn at Okpara (Benin) with nearly $800 \mathrm{~mm}$ in 2003.

\subsubsection{Variables and statistical analysis}

Primary information was recorded on the biophysical and technical sub-systems of the cotton crop, in order to compute the assessment indicators: type and diary of cultural operations, type, amount and price of inputs, and weight, quality and price of the seed cotton harvested from each plot. The ginning out-turn, fibre length and micronaire were estimated from a sample of the crop. The performances of the prototype and the control were analysed each year. Results were pooled across all sites and the annual means were statistically compared, using the residual variance to compute the standard error of the difference between the prototype and the control cotton management system. Between-site variations were not analysed in this paper.

\section{RESULTS AND DISCUSSION}

For one particular set of constraints, we describe step by step how the methodology was implemented, how the prototype was tested on-station, and give the results of its field evaluation.

\subsection{Step 1. Identification of constraints, sets of constraints and criteria}

During the scientific workshop, the constraints to cotton production were analysed. They were pooled into six major sets of constraints (Tab. II), applied to the biophysical subsystem or to the technical sub-system (as defined by Rapidel et al., 2006). The six sets of constraints were ranked according to the frequency of the corresponding situation, and to the chance of developing a new cotton management system which could perform better than the control.

The sets of constraints referred to situations where the main limiting factors for cotton production could be water (1), land (2), pest pressure (3), access to inputs (4), or manpower (5 and 6). Such limiting factors were linked with the major constraints acting on the biophysical or technical sub-system of the crop (Tab. II).

At this step, the experts agreed to assess the prototype for its adaptation to sustainable agriculture standards, by considering three categories of criteria, also called sustainability pillars, and describing the potential impact of the prototype on the farm economy, the environment and the society. The criteria had to be relevant for different groups of stakeholders or beneficiaries, including farmers, ginning companies, extension services, and policy makers. Growers and ginners are most concerned about the economic performance of a cotton management system. Their criteria were associated with agronomic yield, cash income, labour efficiency, and fibre yield and quality, which could contribute to the whole sector's competitiveness and, as such, slightly affect the growers' price. The policymakers would consider a cotton management system as environmentally friendly if it could maintain the soil chemical and biological status, and limit the risks of air, water or soil pollution. Finally, social criteria had to include labour requirements, and also the organisational measures necessary to make this management system applicable, such as farmers' training, input delivery or credit. A crop management system could be considered as applicable if easily adaptable by an ordinary farmer.

\subsection{Step 2. Elaboration of the theoretical prototype and the assessment indicators}

Each set of constraints could be considered to develop a specific prototype of a cotton management system. We gave priority to one of them during the scientific workshop. It was first one listed in Table II, and its story line could be described as follows:

"A cotton grower has a farm located in the Sub-Saharan Sudano-Sahelian zone (one main rainy season, from May to October), where the major cotton pests are two sucking insects, Empoasca minor and Aphis gossypii, and two bollworms Helicoverpa armigera and Spodoptera littoralis. Bacterial blight (Xanthomonas malvacearum) is the major disease. The grower cannot plant all his cotton fields at the recommended time because of labour limitation. He has to grow a late-planted cotton crop on a rather sandy land, but he still intends to get a profit out of it. He is a smallholder, with easy access to all necessary inputs (seed, fertiliser, pesticides, etc.). He can sell his production as seed cotton at a guaranteed price set by the local ginneries. This farmer has to face peaks of labour at sowing and harvesting times."

In comparison with the recommended early-sown cotton, delayed planting reduces the amount of natural resources available for the crop, specially water, but also light, mineralised soil $\mathrm{N}$ and the sum of temperatures, and shifts the impact of other constraints such as insect attacks or labour competition.

Figure 2 shows how delayed planting changes the crop environment, and limits the potential seed cotton yield by as much as 150 to $200 \mathrm{~kg} / \mathrm{ha}$ per week of delayed planting (Lançon et al., 1989).

The experts designed a theoretical prototype adapted to the target set of constraints, and planned its experimentation. At the regional meeting, two groups agreed on a preliminary version of the theoretical prototype. This version was later adapted to local situations (based on available knowledge, resources, genetic material, input and equipment) during 


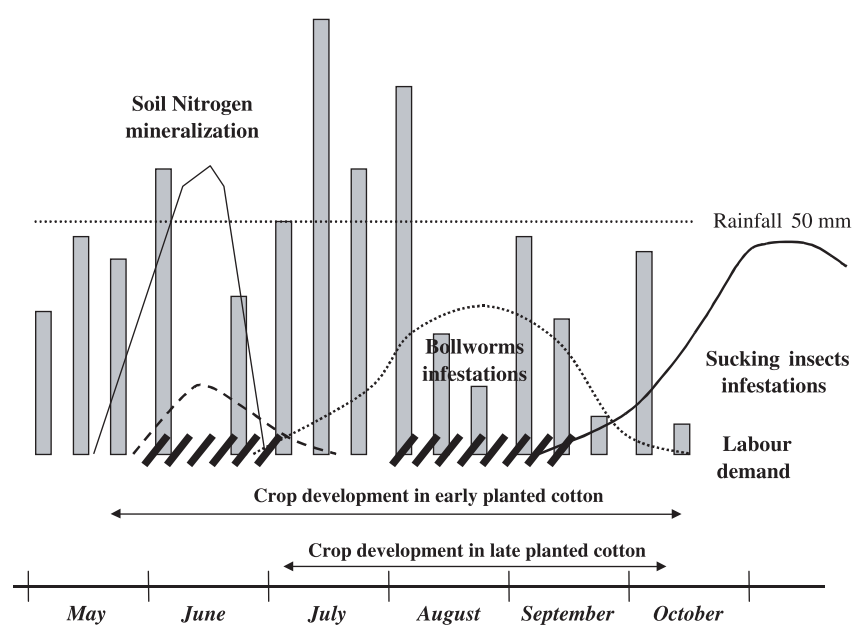

Figure 2. Incidence of biophysical and labour constraints on cotton development with two different dates of planting (early and late) in West Africa. The major biophysical constraints include nitrogen mineralisation (plain line on the left), rainfalls (vertical bars), sucking pests (dashed line), and bollworm main attacks (dotted line). Labour peaks are also indicated (slash).

the following workshops (Tab. I). Extension staff and farmers were indirectly associated with this process through field visits and discussions. They expressed concerns about input costs, labour limitation and mechanical weeding. Such concerns made the agronomists restrain the amount of fertilisers and pesticides used in the theoretical prototype, exclude too narrow inter-row spacing and add indicators to monitor the labour needs.

While elaborating the theoretical prototype, priority was given to the factors affecting cotton field performance, although economic, environmental and social constraints were also considered. The theoretical prototype had to take into account labour productivity, fibre quality for export and utilisation of pesticides. Bearing in mind the same conceptual model of cotton yield elaboration as the one proposed by Rapidel et al. (2006), the experts wanted the crop duration match the climatic potential, either by shortening the growth period, increasing the time of favourable conditions for growth or by avoiding affecting the potential. Relevant techniques aimed at improving the crop efficiency, or hastening its cycle, increasing the soil fertility or its water storage capacity, enhancing chemical and biological activation of the deeper horizons, increasing light interception by the canopy, and protecting the crop against weeds or insects. Techniques which could hasten soil preparation, sowing realisation, seed emergence and early canopy closure were also considered. Due to the rainfall pattern, the crop could not extend its growth period beyond October and competition for water had to be controlled at an early stage.

Ploughing, seed delinting and high stand were proposed to hasten, respectively, sowing, seed emergence and early canopy closure. Ploughing was preferred to minimum tillage, because it increased the chance of the seeds germinating. When planted late, the cotton crop must be established at once as it can hardly compensate for a poor stand. High density was expected to produce a beneficial effect at the beginning of the cycle until the canopy covered the inter-row. Weed control was ensured by tillage, pre-planting herbicide, high densities and hand weeding until canopy closure. Plant competition was managed through growth-regulator spraying after this stage. Protection of the yield potential established with these techniques was obtained with 6 applications of insecticides against bollworms, leaf-eaters and sucking insects. Protection against bollworms was maintained from the beginning of flowering to the end of the boll susceptibility period (Fig. 2). Leaf-eaters are dangerous in the early development phases when the canopy develops and also later during the boll-filling periods. Finally, aphids or white flies can affect boll size and fibre quality, as late-planted cotton often remains with attractive, long-lasting leaves.

The ideal variety for this theoretical prototype should combine fast seed germination, early flowering and boll opening, and early canopy closure to avoid soil evaporation. It should also produce a fibre of sufficient quality for export, i.e. equivalent to the local commercial varieties.

The differences between the cotton management system recommended to farmers, the theoretical prototype designed by expert groups, and the experimental prototype implemented in our experiments are listed in Table III. They include genotypes with earlier boll opening, faster canopy closure and shorter habit, increased plant stand, lower rates of fertilisers (no urea), use of herbicides (pre-planting) and growth regulators, and a reduced spray regime against pests.

The assessment indicators (Tab. IV) were derived from the criteria previously selected by the experts at the scientific workshop: agronomic and economic performance, environmental impact and social acceptability.

The economic performance of the cotton management system was assessed by means of six indicators. Seed cotton yield and ginning out-turn were directly linked with farmers' revenue. The net income was the amount of money left for the producer once all the inputs had been paid back. It was divided by the number of working days to express the labour revenue. Fibre length and micronaire were considered as necessary indicators for the international market.

In the absence of computer models or sufficient local databases to compute environmental indicators such as those proposed by Girardin et al. (2000), we had impose a limit of three environmental indicators: excess of $\mathrm{N},(\mathrm{P}+\mathrm{K})$ balance, and number of pesticide applications. In the considered cottongrowing areas, we expected a sustainable cotton management system to be characterised by a limited amount of nitrogen excess, as well as a positive balance of $\mathrm{P}$ and $\mathrm{K}$ applied to the crop minus the amount exported through the harvest. Very high excess of $\mathrm{N}$ or $\mathrm{P}$ could affect the quality of the water either drained into the soil, or collected by the rivers. In a simplified approach, we also considered the number of chemical sprays as directly related to the amount of pesticides and their impact on the environment. Although the organic matter balance should be considered as a good indicator of soil fertility (Bertrand and Gigou, 2000), we were not able to estimate it properly in these experiments. 
Table III. Comparison of the cropping techniques recommended to the farmers, or included in the control cotton management system, the theoretical prototype and the experimental prototype.

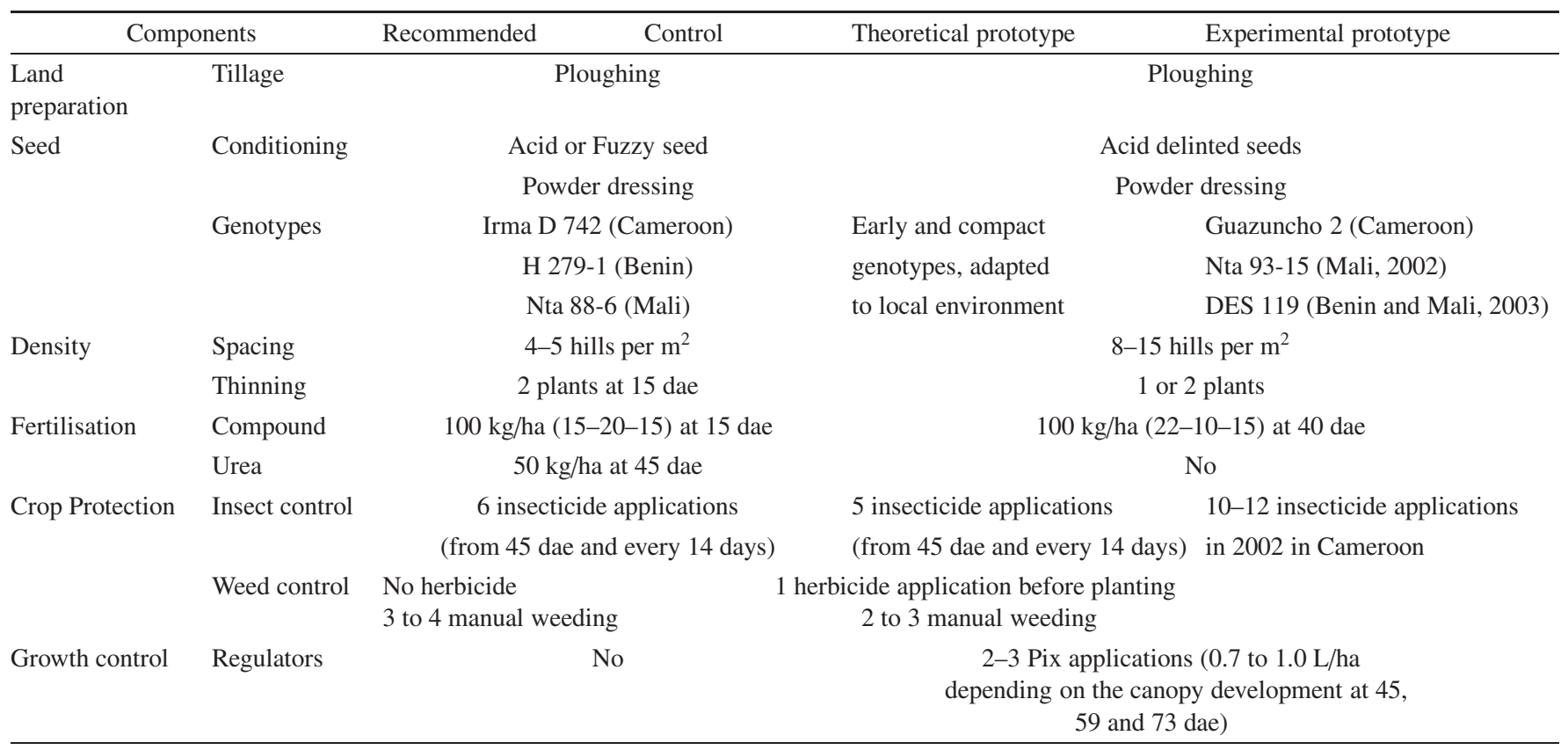

Four social indicators were selected to evaluate the chance of a crop management system to be adopted by an ordinary farmer. The indicators dealt with the amount of labour needed, and also with technical or organisational measures necessary to disseminate the crop management system, training of farmers or inputs delivery. They induded the amount of labour required, especially during the busiest periods, the cost of inputs and, during on-farm testing, the number of operations which could not be handled properly without specific and intensive training.

\subsection{Step 3. On-station evaluation of the experimental prototype}

The theoretical prototype was common to all sites, but the experimental prototype was adjusted locally to the expected pest pressure (Cameroon, 2002) or to the existing genetic material. These modifications are part of the methodology, as they contribute to the assessment of the technical feasibility of the theoretical prototype. In our case, they mainly concerned crop protection, varieties and growth regulator applications (Tab. III). The genetic material available could not combine all the desired traits to fit the cotton management system requirements, i.e. earliness, good adaptation to the local environment and high quality fibre. The varieties included in the prototypes were only substitutes. Nta 93-15 was bred in Mali but not as early as was desirable, while Guazuncho 2 and DES 119 were early-maturing but not very well adapted to the local environmental and market constraints. The control cotton management system received a preliminary herbicide application in order to equalise the weed pressure at the beginning of the experiment.

In most situations, the experimental prototype produced more fibre, and it improved farmers' income and labour productivity (Tab. V).

The prototype over-yielded the recommended cotton management system at 13 out of 14 experimental sites, giving an average increase of 35\% in 2002 and $23 \%$ in 2003. In 2002, the prototype partly escaped higher drought stress, and benefited from reinforced insect control in Cameroon (Tab. III). The advantage of the prototype was higher when the control yielded less (Fig. 3), i.e. with late planting and low rainfall available to the crop. As these conditions fit with the target set of constraints, they are particularly useful for assessing the prototype.

The prototype improved farmers' revenue by about $35 \%$ in 2002 ( $70 € /$ ha) and $20 \%$ in 2003 (50€/ha). The results, however, ranged from a loss of $20 €$ (Okpara in 2003) to a gain of $152 € /$ ha (Farako in 2003). Labour productivity was also increased by about 5 to $20 \%$ for the prototype, i.e. $0.5 \mathrm{~kg}$ seed cotton per day of work in 2002 and only $0.2 \mathrm{~kg} /$ day in 2003 . Differences between years were due to the amount of labour needed for picking the harvest, and also to the differential raise in input prices and costs.

In 2003, the ginning percentage of the prototype was 3 to 4 points lower than the control, except in Kodek, where the same commercial variety was used for the prototype and the control. The fibre of the prototype was also inferior in quality, due to lower maturity or length. This was the consequence of inadequate varieties.

Both years, the prototype achieved a satisfactory environmental performance, although it never performed better than 
Table IV. Criteria and indicators to assess the cotton management systems. The criteria were selected during the initial scientific workshop. The indicators were also chosen during this workshop, but were then modified in local workshops.

\begin{tabular}{|c|c|c|c|c|}
\hline Sustainability Pillar & Stakeholders & Criteria & Indicator & Computation \\
\hline \multirow{6}{*}{ Economic } & \multirow{3}{*}{ Farmer } & Field production & Yield & Seed cotton harvested/ha \\
\hline & & Cash income & Net income & Crop revenue-input costs \\
\hline & & Labour efficiency & Net income/day & Net income/total labour \\
\hline & \multirow{3}{*}{ Ginning Company } & Fibre yield & Ginning out-turn & Percentage of fibre in the seed cotton \\
\hline & & \multirow{2}{*}{ Fibre quality } & Length & Direct reading (HVI) \\
\hline & & & Micronaire & Direct reading \\
\hline \multirow{4}{*}{ Environmental } & Farmer & Soil chemical fertility & $\mathrm{P}+\mathrm{K}$ balance & Supply - exportations ${ }^{\dagger}$ \\
\hline & \multirow{3}{*}{ Governmental agencies } & Soil biologic fertility & Organic matter & Not considered \\
\hline & & Air or soil pollution & Pesticide pressure & Number of pesticide sprays \\
\hline & & Water pollution & $\mathrm{N}$ balance (excess) & Supply - exportations ${ }^{\dagger}$ \\
\hline \multirow{4}{*}{ Social } & \multirow{4}{*}{ Farmer } & \multirow{2}{*}{ Labour requirement } & Total labour & Estimated number of working days ${ }^{\dagger \dagger}$ \\
\hline & & & $\%$ in the busy time & $\%$ working days in period $3^{\dagger \dagger}$ \\
\hline & & Frequency of interventions & Number of operations & Number of field operations \\
\hline & & Operation costs & Input costs & Sum of all input costs \\
\hline
\end{tabular}

$\dagger$ Balance: inputs - exportations by the crop (after Braud, 1987).

$\dagger \dagger$ Labour norms in men-days per ha; Sowing: depending on the number of holes $/ \mathrm{m}^{2}$; Thinning: 1; Fertiliser application: 2; Weeding: 10; Spraying: 0.5; Harvest: variable (between 10 and $50 \mathrm{~kg}$ depending on the amount of cotton available for each picking). These norms are similar for the prototypes and the control, except for Sowing (proportional to the expected stand) and $\mathrm{H}$ (proportional to the amount of harvest available at each picking). $\dagger \dagger$ Quantity of labour in the busiest period. Labour requirements are given a weight from 1 to 3 according to the demand in that period.

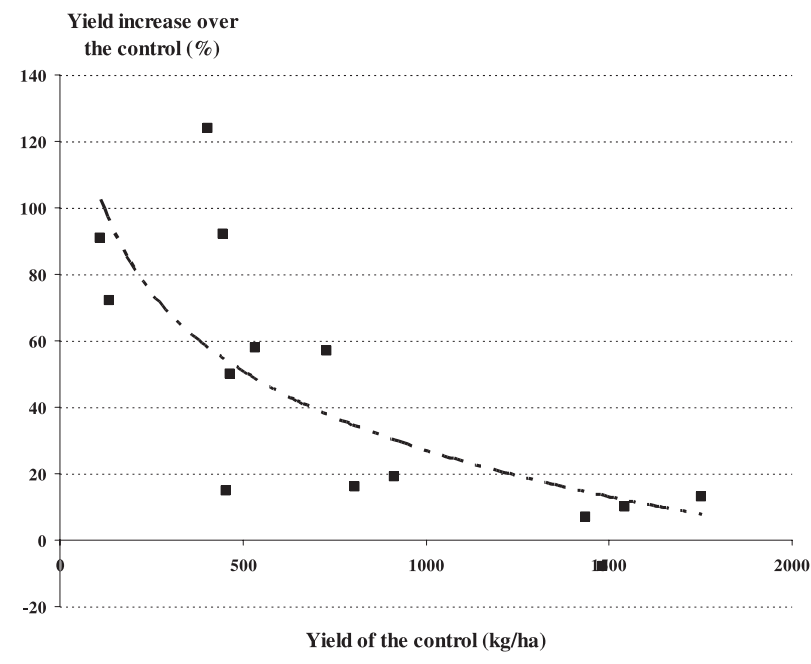

Figure 3. Relationship between the relative yield gain provided by the prototype (compared with the control cotton management system) and the control yield as an indicator of site potential. The data come from two years: 2002 (6 locations in 2 countries) and 2003 (8 locations in 3 countries). The points fit the Log curve $\mathrm{Y}=264-34.4$ $\mathrm{Ln}(\mathrm{X})$ with $\mathrm{R}^{2}=0.54$. The clear decreasing tendency indicates that the advantage of the prototype over the control is higher on sites with lower potential.

the control (Tab. V). Mineral balances were positive but not in large excess. At the highest levels of yields (Sotuba in 2002, Kodek and Okpara in 2003), the crop exported more than the supply by fertiliser. The number of insecticide sprays was higher in Cameroon in 2002 (Tab. III), due to an excessive fear by the researchers of uncontrolled pest infestation, but this was adjusted to the control level in 2003.

The social performance of the experimental prototype was lower than the control (Tab. V), particularly in 2002. It required more labour, especially for planting and harvesting, at busy periods where most agricultural activities are under pressure. It also cost more to implement, and was technically more demanding (number of operations). In 2003, the situation improved for the last two indicators after the number of insecticide sprays was reduced.

As a whole, the prototype performed as planned by the experts, but it showed two major drawbacks: it neither quite matched the market standards of quality, nor reduced the environmental impact of the cotton crop. New research on individual techniques should overcome these limitations. They need to be implemented in the adjustment phase of the prototype (transition between step 3 and step 4 in Fig. 1). The ongoing work on plant breeding (Sêkloka, 2006), integrated pest management (Ratnadass et al., 2003), and plant growth regulators (Barrabe et al., submitted) are likely to improve the performance of the prototype at both economic and environmental levels. In the near future, the use of more determinate varieties adapted to this particular set of constraints, but with high ginning out-turn and good fibre quality, should improve the economic performance of the prototype. Its sustainability could also be improved by adjusting the fertiliser rates to the production target, and the protection regime to the actual pest pressure. Improving the acceptability of the prototype would probably go along with intensification, a wider use of animal 
Table V. Assessment of the experimental prototype in relation to the three sustainability pillars. The results of the prototype are compared with the control cotton management system.

\begin{tabular}{|c|c|c|c|c|c|c|c|}
\hline \multirow{2}{*}{ Sustainability Pillar } & \multirow{2}{*}{ Indicator } & \multicolumn{3}{|c|}{2002 (6 locations) } & \multicolumn{3}{|c|}{2003 (8 locations) } \\
\hline & & Control & Prototype & s.e. $^{1}$ & Control & Prototype & s.e. $^{1}$ \\
\hline \multirow{6}{*}{$\begin{array}{l}\text { Economic } \\
(\text { short-term) }\end{array}$} & Yield (ton seed cotton/ha) & 0.72 & $0.97 *$ & 0.10 & 0.86 & $1.02 *$ & 0.14 \\
\hline & Net income (€/ha) & 123 & 155 & 22 & 140 & 187 & 45 \\
\hline & Net income per working day (€) & 1.59 & 1.75 & 0.36 & 1.53 & 2.01 & 0.58 \\
\hline & Ginning out-turn (\%) & 41.6 & 41.8 & 0.9 & 44.0 & $40.3 *$ & 1.7 \\
\hline & Length (mm) & 29.0 & 28.4 & 0.7 & 29.8 & $29.1 *$ & 0.7 \\
\hline & Micronaire & 3.2 & $2.9^{*}$ & 0.2 & 4.1 & 4.0 & 0.3 \\
\hline \multirow{3}{*}{$\begin{array}{l}\text { Environmental } \\
\text { (long-term) }\end{array}$} & $\mathrm{P}$ and $\mathrm{K}$ balance $(\mathrm{kg} / \mathrm{ha})$ & 11.8 & $8.7 *$ & 1.2 & 33.9 & 26.4 & 10.6 \\
\hline & Number of pesticide sprays & 6.0 & $8.7 *$ & 1.5 & 6.5 & 6.6 & 0.8 \\
\hline & $\mathrm{N}$ balance $(\mathrm{kg} / \mathrm{ha})$ & 17.7 & $12.8^{*}$ & 1.8 & 16.0 & $1.3^{*}$ & 10.5 \\
\hline \multirow{4}{*}{$\begin{array}{l}\text { Social } \\
\text { (acceptability) }\end{array}$} & Total labour (men-days) & 66.4 & $75.2^{*}$ & 4.0 & 76.6 & $86.7^{*}$ & 6.0 \\
\hline & Labour in the busiest period $(\%)$ & 43 & $55^{*}$ & 7 & 79 & 81 & 5 \\
\hline & Number operations & 13.8 & $18.7 *$ & 1.4 & 15.0 & $17.8^{*}$ & 0.6 \\
\hline & Input costs (ton seed cotton/ha) & 0.28 & $0.42 *$ & 0.04 & 0.37 & 0.38 & 0.02 \\
\hline
\end{tabular}

\footnotetext{
${ }^{1}$ Standard error for the difference between the control and the prototype.

* The difference between the control and the experimental prototype is significant at the $5 \%$ level.
}

draught power to reduce labour, and an increased seed cotton price to compensate for high input costs.

The prototyping method, as proposed in this paper, is well suited to complex situations, which require a multidisciplinary approach to deal with multiple objectives, and a large set of techniques. It is also relevant for assessing the sustainability components of agricultural activities, at different scales, and from various agronomic, economic, environmental or social perspectives. In choosing a target set of constraints and a set of assessment criteria (Step 1 in Fig. 1), the scientists in charge of the experiment have to integrate various views on the crop in its target environment. Such a choice helps them to select the experimental sites, and the relevant indicators to measure in the field. We show here that the translation of multi-stakeholder's expectations in field experiments can be implemented in African as well as in European conditions (Loyce et al., 2002). The cotton commodity chain provides a good example, as it involves many categories of stakeholders, from farmers to policy-makers, each pursuing different goals. The prototyping approach would be particularly appropriate for designing management systems for organic cotton, which is a multipurpose (textile, food and feed) and multifunctional crop (farmer's income, industry income, environmental safety and fair trade), grown in sub-optimal environments, with a limited range of inputs, and facing organisational constraints at a farm level.

The results of the Experimental Prototype show that the prototyping approach was useful for designing an innovative cotton management system with complex combinations of techniques and genotypes which had not been experimented in this environment. The approach made use of the broad disciplinary knowledge and know-how of scientists and local experts. From the experience of the interdisciplinary workshops, we are convinced that none of the experts would have achieved on his own the same prototype, because each expert had a different point of view on the biophysical system. During the elaboration of the prototype, and even more, during its adjustment (not described here), the experts found it difficult to share a common vision of the system. This was indeed the weakest point of the interdisciplinary process conducted in this work. The potential of model-based prototyping to elaborate a theoretical prototype adapted to a target set of constraints has been demonstrated by Dogliotti et al. (2004). The lack of such a model revealed the need to develop a conceptual model of the cropping system as a tool to facilitate the elaboration and the adjustment of the prototype. The one proposed by Rapidel et al. (2006), and tested in African cotton fields, should help in this new methodological development.

\section{CONCLUSION}

This article describes the first steps of an experiment-based prototyping method, from the identification of the target set of constraints, to the conception of an innovative combination of techniques, and its multi-criteria assessment by on-station field experiments. It was applied to cotton production in West Africa, where expert knowledge is poorly capitalised in the scientific literature and crop models. The major sets of constraints for cotton production were identified and agreed upon. One set of constraints was selected and a prototype for a new cotton management system was designed. The prototype resulted in a combination of technical interventions that had not been experimented on before in Western Africa. It was locally adapted to match the local interests and means of the stakeholders. Sets of indicators were selected to assess the 
main performance of this prototype, covering the three pillars of sustainability. In comparison with the cotton management system recommended by the extension services, it showed interesting economic results for the farmers in almost all test locations. Environmental indicators showed satisfactory performance. As it still requires extra labour and skills, adjustments are needed to finalise the prototype. These adjustments have been performed in Mali with on-station experimentation using the indicators of crop functioning identified in Step 2. They will be described in a companion paper. The best prototypes produced by Step 3 are currently under assessment and adjustment in a participatory approach with farmers (Step 4 in Fig. 1).

Acknowledgements: Many scientists contributed to this work. The main contributors only could be cited as authors. We would like to thank all those who attended the initial workshop and contributed to the first step of the method. Besides the many CIRAD scientists, we wish to particularly mention J.P. Mvondo Awono (Dschang University), A. Yattara (IER), P. Debaeke, J.M. Meynard and P. Robin (INRA), D. Arodokoun and A. Hougni (INRAB), C. Klassou (IRAD), and P. Asfom (SODECOTON). We also wish to mention the CIRAD scientists who actively supported this experiment and could not be included as authors: T. Brévault, J.P. Deguine, P. Dugué, M. Fok, G. Gawrysiak and P. Prudent. This work was supported by the cotton development organisations in Mali (CMDT), Cameroon (SODECOTON) and Benin (SONAPRA), by the French Ministry of Foreign Affairs (MAE) in Mali and Benin, and by CIRAD in all three countries.

\section{REFERENCES}

Baker D.N., Lambert J.R., McKinion J.M. (1983) Gossym: A simulator of cotton crop growth and yield, Technical Bulletin 1089, Agric. Exp. Stn, Clemson University, Clemson, SC.

Barrabe A., Rapidel B., Sissoko F., Traoré B., Wery J., Elaboration and test of a decision rule for the application of Mepiquat Chloride on cotton in Mali, Eur. J. Agron., submitted.

Bertrand R., Gigou J. (2000) La fertilité des sols tropicaux, Maisonneuve et Larose, Paris, 397 p.

Braud M. (1987) La fertilisation d'un système de culture dans les zones cotonnières soudano-sahéliennes, Coton Fib. Trop. 42, 7-35.

Cauquil J., Vaissayre M. (1994) Protection phytosanitaire du cotonnier en Afrique tropicale, Agr. Dev. 3, 4-12.

CIRAD (1999) Le coton au Sud, Economie, agriculture, transformation, recherche, Agr. Dev. 22, 120 p.

CMDT (2001) Note sur l'utilisation des engrais chimiques en zone CMDT, Campagne 2001/2002, CMDT, DTDR, LRD, Bamako, Mali.

Crétenet M., Vaissayre M. (1986) Modèle de décision appliquée à l'interaction entre fumure minérale et protection phytosanitaire en culture cotonnière, Coton Fib. Trop. 41, 89-96.
David C., Jeuffroy M.H., Henning J., Meynard J.M. (2005) Yield variation in organic winter wheat: a diagnostic study in the Southeast of France, Agron. Sustain. Dev. 25, 213-223.

Dogliotti S., Rossing W.A.H., van Ittersum M.K. (2004) Systematic design and evaluation of crop rotations enhancing soil conservation, soil fertility and farm income: a case study for vegetable farms in South Uruguay, Agr. Syst. 80, 277-302.

Dugué P., Floquet A. (2000) Mission d'appui pour la programmation du volet recherche-développement du projet d'amélioration et de diversification des systèmes d'exploitation (PADSE), Agence Française de développement, Cotonou, Bénin.

Girardin P., Bockstaller C., Van der Werf H. (2000) Assessment of potential impacts of agricultural practices on the environment: The AGRO*ECO method, Environ. Impact Assessment Rev. 20, $227-$ 239.

Haefele S.M., Wopereis M.S.C., Donovan C., Maubuisson J. (2001) Improving the productivity and profitability of irrigated rice production in Mauritania, Eur. J. Agron. 14, 181-196.

Hau B., Goebel S. (1987) Modifications du comportement du cotonnier en fonction de l'environnement. 2. Évolution des paramètres de productivité de neuf variétés semées à trois écartements, Coton Fib. Trop. 42, 117-125.

Hearn A.B. (1994) OZCOT: a simulation model for Cotton crop management, Agr. Syst. 44, 257-299.

Joly A. (1976) Expérimentation sur les régulateurs de croissance au NordDahomey, Coton Fib. Trop. 31, 273-281.

Lançon J., Klassou C., Chanselme J.L. (1989) Influence de la date de semis sur certaines caractéristiques technologiques de la fibre et de la graine de coton (Gossypium hirsutum L.) au Nord-Cameroun, in: Berger and Frydrych (Eds.), Actes : 1 conférence de la recherche cotonnière africaine, Lomé, Togo, CIRAD, Montpellier, France, Vol. 1, pp. 241-251.

Loyce C., Rellier J.-P., Meynard J.-M. (2002) Management planning for winter wheat with multiple objectives: the BETHA system, Agr. Syst. 72, 9-31.

Rapidel B., Defèche C., Traoré B., Lançon J., Wery J. (2006) In field development of a conceptual model for crop functioning and management: a case study on Cotton in Southern Mali, Eur. J. Agron. $24,304-315$.

Ratnadass A., Mourichon X., Vaissayre M., Quilici S., Deguine J.P. (2003) Integrated Pest Management experiences of Cirad in developing countries, in: Maredia K.M., Dakouo D., Mota-Sanchez D. (Eds.), Integrated Pest Management in the Global Arena, CABI Publishing, Cambridge, USA, pp. 453-465.

Sêkloka E. (2006) Amélioration de l'efficacité de la sélection pour le rendement en coton graine du cotonnier G. hirsutum L. dans le contexte de nouveaux itinéraires techniques, Thèse de doctorat, ENSARennes, 142 p.

Vereijken P. (1997) A methodological way of prototyping integrated and ecological arable farming systems (I/EAFS) in interaction with pilot farms, Eur. J. Agron. 7, 235-250. 